\title{
Response of mass selection in maize (Zea mays $\mathrm{L}_{\text {.) }}$
}

\author{
Jiban Shrestha $^{1,2^{*}}$, Chitra Bahadur Kunwar ${ }^{2 * *}$ and Balram Bhandari ${ }^{\text {**** }}$ \\ ${ }^{1}$ Nepal Agricultural Research Council, National Commercial Agriculture Research Program, Pakhribas, \\ Dhankuta, Nepal \\ ${ }^{2}$ National Maize Research Program, Rampur, Chitwan, Nepal \\ *E-mail: jibshrestha@gmail.com \\ **E-mail: chitra2058@gmail.com \\ ***E-mail: balram.bhandari2009@gmail.com
}

\begin{abstract}
This study was conducted to quantify the progress towards grain yield and agronomic traits in maize genotypes through mass selection. The original maize population and the population derived after five cycles of mass selection were planted for comparison at research field of National Maize Research Program, Rampur, Chitwan, Nepal during winter season of 2011-2012. The maize genotypes were Arun-1EV, Arun-4, Pool-17, P501SRCO $\times$ P502SRCO, BGBYPOP, Across9942 × Across9944, S99TLYQ-B, S99TLYQ-AB and S01SIWQ-3, respectively. The experiment was laid down in randomized complete block design with three replications. Each replication consisted of 180 rows; 20 rows of each genotypes. The results showed that there was significant reduction in plant height, ear height, tasseling days, silking days, disease severity however significant increment in grain yield. The results showed that phenotypic superiority of the selected population over the original population was obvious.
\end{abstract}

Key words: Maize genotypes, Ass selection, Agronomical traits, Grain yield.

DOI: http://dx.doi.org/10.3126/on.v16i1.22119

Manuscript details: Received: 28.04.2018 / Accepted: 25.07.2018

Citation: Shrestha, J., C.B. Kunwar and B. Bhandari 2018. Response of mass selection in maize (Zea mays L.), Our Nature 16(1): 35 42. DOI: http://dx.doi.org/ 10.3126/on.v16i1.22119

Copyright: $\odot$ Shrestha, Kunwar and Bhandari 2018. Creative Commons Attribution - Non Commercial 4.0 International License.

\section{Introduction}

The mass selection is a breeding method in which individual plants are selected on the basis of phenotypes and a balanced seed bulk from the selected plants is composited to propagate next selection cycle. Prior to the selection of individuals, crop is grown in the field which is first divided into smaller selection units (field stratification), minimizing the bias due to field heterogeneity. The differences among plants within field's sections are more likely to be due to genetic differences than to environmental effects (Hallauer et al., 2010). Mass selection has been successfully used by maize growers to increase productivity (Gardner, 1977; Zorilla and Crane, 1982) and yield components (Salazar and Hallauer, 1986; Odhiambo and Compton, 1987). Maize breeders have suggested the possibility of producing superior open pollinated varieties (OPV) from advanced cycles of selected populations in developing countries (Eberhart et al., 1967; Darrah et al., 1978).

The phenotypic performance based on the selection of individual plants is the simplest way to improve crops. Lonnquist (1967) who applied five generations of mass selection to increase productivity in maize using correlated characters for prolificacy found that the gain in yield per cycle of $6.25 \%$ approximated that obtained when direct selection was used for weight of grain per plant. After 10 cycles of mass selection for prolificacy in maize composite $\mathrm{BC} 10$, grain yield was increased by $2.6 \%$ per cycle (Subandi, 1990). The grain yield was increased significantly with the application of all the 
selection criteria used, which included ear length, prolificacy, anthesis-silking interval and harvest index (Biasutti et al., 2000). Specifically, for the length of the ear, an increase of $2.8 \%$ was reported after four selection cycles were performed. The 10 cycles of mass selection for yield in the maize cultivar (Zacatecas 58) resulted in an average genetic advance of $3.25 \%$ per cycle (Vargas et al., 1982). Although mass selection has been used primarily to improve performance, its usefulness in improving other plant characters has also been documented. A gain of $3.3 \%$ per cycle in the emergence of seedlings using mass selection (Bell et al., 1983). Similarly, Cortez-Mendoza and Hallauer (1979) who exercised mass selection in ear length for IOWA Long Ear Synthetics and observed that 10 cycles of mass selection produced a highly significant average increase of $0.32 \mathrm{~cm}$ per generation. In Nepal stratified mass selection are generally used for maintenance and improvement of promising prerelease and released maize varieties.

The objectives of this study were to quantify the progress in grain yield and other agronomic traits in maize genotypes namely Arun-1EV, Arun-4, Pool-17, P501SRCO $\times$ P502SRCO, BGBYPOP, Across9942 $\times$ Across9944, S99TLYQ-B, S99TLYQ-AB and S01SIWQ-3 at Rampur, Chitwan condition of Nepal.

\section{Materials and methods \\ Experimental site and genetic materials}

This experiment was conducted at research field of National Maize Research Program (NMRP), Rampur, Chitwan $\left(27^{\circ} 37^{\prime} \mathrm{N}\right.$ and $84^{\circ} 25^{\prime} \mathrm{E}$, alt. $256 \mathrm{~m}$ asl), Central Nepal during winter season (from September 2011 to February 2012).

Multiple agronomic traits selection in 9 maize genotypes were derived from original and selected populations namely Arun-1EV, Arun-4, Pool-17, P501SRCO $\times$ P502SRCO, BGBYPOP, Across9942 $\times$ Across 9944, S99TLYQ-B, S99TLYQ-AB and S01SIWQ-3 The selected maize population (derived after five cycles of mass selection) was received from Plant Breeding section of NMRP office.

\section{Experimental design, details and cultural practices}

The experiment was laid down in randomized complete block design with three replications. Each replication consisted of 180 rows; 20 rows of each genotype (i.e. 10 rows for genotype from original population and 10 rows for genotype from selected population). Row length was $5 \mathrm{~m}$, which were row spaced at $75 \mathrm{~cm}$ and the plant to plant spacing was $25 \mathrm{~cm}$ resulting in a population of about 53,333 plants/ha. The main objective of the study was to observe the effects of multiple traits selection after five cycles of mass selection in comparison to original (unselected) population. Selection was made on the basis of phenotypic superiority. A random sample of hundred plants was taken from each plot for comparison of grain yield and other agronomic traits.

Irrigations were provided on basis of as required during the entire crop season. A basal dose of fertilizer of $120 \mathrm{~kg}$ nitrogen, $60 \mathrm{~kg}$ of phosphorus and $40 \mathrm{~kg}$ of potash was applied in the form of urea, DAP and MoP. Full dose of phosphorus and potash along with half dose of nitrogen was applied at the time of seed sowing. The remaining half dose of nitrogen fertilizer was side dressed when plants were $10-15 \mathrm{~cm}$ tall. Diazinon $10 \mathrm{G}$ was used in shoots after 25 days of sowing followed by spot application thereafter, whenever required for the control of maize stem borer. Standard cultural practices were applied from sowing till harvest.

\section{Data collection and analysis}

Data were recorded on the agronomic parameters using either standing crop or the harvested material. Plant height, ear height, plant aspect, ear aspect and disease score were recorded.

Disease severity scale and reaction type was recorded as below;

1 = Resistant, Plants with one or two to few scattered lesions on lower leaves

$2=$ moderately resistant, Moderate number of lesions on leaves, affecting less than 25 percent of the area

$3=$ moderately susceptible, Abundant lesions on lower leaves, few on other leaves affecting 26- $50 \%$ leaf area

$4=$ Susceptible, Lesions abundant on lower and mid leaves, extending to upper leaves affecting $51-75 \%$ leaf area

$5=$ Lesions abundant on almost all leaves, plant prematurely dried or killed with $76-100 \%$ of the leaf area affected.

Plant aspect scoring was done from 1-5 scale where $1=$ short plant with uniform and short ear placement, 5= tall plant with higher ear placement. 
The ear aspect was scored from 1-5, where $1=$ nice and uniform cobs with desirable texture in the area, $5=$ ugly cobs with undesirable texture in the area.

Grain yield $(\mathrm{kg} / \mathrm{ha})$ at $15 \%$ moisture content was calculated using fresh ear weight following Carangal et al. (1971) and Shrestha et al. (2018) as follows:

$$
\text { Grain yield }\left(\frac{\mathrm{kg}}{\mathrm{ha}}\right)=\frac{\text { F.W. }\left(\frac{\mathrm{kg}}{\mathrm{plot}}\right) \times(100-\mathrm{HMP}) \times \mathrm{S} \times 10000}{(100-\mathrm{DMP}) \times \mathrm{NPA}}
$$

Where,

F.W. = Fresh weight of ear in $\mathrm{kg} / \mathrm{plot}$ at harvest

HMP $=$ Grain moisture percentage at harvest

$\mathrm{DMP}=$ Desired moisture percentage, i.e. $15 \%$

NPA $=$ Net harvest plot area, $\mathrm{m}^{2}$

$\mathrm{S}=$ Shelling coefficient, i.e. 0.8

\section{Statistical analysis}

Statistical analysis was carried out for the abovementioned traits using computer software MSTATC version 6.4.1. Least significant difference test was used at 0.05 probability level for the separation among the population means (Gomez and Gomez, 1984).

\section{Results}

\section{Tasseling days}

The days to $50 \%$ tasseling was highly significant for genotypes. The difference in days to $50 \%$ tasseling was observed 12 to 14 days earlier in selected population of OPV full season than original population. The days to tasseling were observed 6 days earlier to 9.5 days later than original population of quality protein maize (QPM) varieties whereas, 6 days earlier to 4 days later days to tasseling than original population of OPV early. In this study the difference in days to tasseling was higher in OPV full season than the QPM and OPV early because of more selection pressure was given to OPV full season varieties than other varieties (Table 1).

\section{Silking days}

The days to $50 \%$ silking were highly significant for genotypes. The difference in days to $50 \%$ silking was observed 11 to 16 days earlier in selected population of OPV full season than original population. The days to silking were observed 4 days earlier to 9 days later than original population of QPM varieties whereas, 2 days earlier to 3 days later days to silking than original population of OPV early. In this study the difference in days to silking was higher in OPV full season than the QPM and OPV early because of more selection pressure was given to OPV full season varieties than other varieties (Table 1).

\section{Plant height}

The difference in plant height was observed 26 to $40 \mathrm{~cm}$ shorter in selected population of OPV full season than original population. The plant height was observed 10 to $53 \mathrm{~cm}$ shorter than original population of QPM varieties whereas, 5 to $10 \mathrm{~cm}$ shorter than original population of OPV early. In this study the difference in plant height reduction was higher in QPM than the OPV full season and OPV early because of more selection pressure was given to QPM varieties than other varieties (Table 2).

\section{Ear height}

The ear height was highly significant for genotypes. The difference in ear height was observed 6 to $17 \mathrm{~cm}$ shorter in selected population of OPV full season than original population. The ear height was observed 10 to 18 $\mathrm{cm}$ shorter than original population of QPM varieties whereas, 1 to $5 \mathrm{~cm}$ shorter than original population of OPV early. In this study the difference in ear height reduction was higher in OPV full season than the QPM full season and OPV early because of more selection pressure was given to OPV full season than other varieties (Table 2).

\section{Plant and ear aspect}

The plant aspect and ear aspect were nonsignificant for genotypes. The the difference in plant aspect was observed 0.7 to 1 lower in selected population of OPV full season than original population. The plant aspect was observed 0.8 to 1.8 lower than original population of QPM varieties whereas, 0.9 to 1.8 lower than original population of OPV early. In this study the difference in plant aspect reduction was higher in QPM than the OPV full season and OPV early because of more selection pressure was given to QPM varieties than other varieties (Table 3).

The difference in ear aspect was observed 0.1 to 0.5 lower in selected population of OPV full season than original population. The ear aspect was observed 0 to 1.4 lower than original population of QPM varieties whereas, 0.5 to 1.7 
Shrestha, Kunwar and Bhandari / Our Nature (2018), 16 (1): 35-42

Table 1. Comparative study of maize genotypes derived from original and selected population for flowering days at Rampur, Chitwan, 2011-12 winter season

\begin{tabular}{|c|c|c|c|c|c|c|}
\hline \multirow[t]{2}{*}{ Genotypes } & \multicolumn{3}{|c|}{$50 \%$ Tasseling days } & \multicolumn{3}{|c|}{$50 \%$ Silking days } \\
\hline & $\begin{array}{l}\text { Original } \\
\text { population }\end{array}$ & $\begin{array}{l}\text { Selected } \\
\text { population }\end{array}$ & Difference & $\begin{array}{l}\text { Original } \\
\text { population }\end{array}$ & $\begin{array}{l}\text { Selected } \\
\text { population }\end{array}$ & Difference \\
\hline \multicolumn{7}{|l|}{ OPV Full season } \\
\hline $\begin{array}{l}\text { Across } 9942 \times \\
\text { Across } 9944\end{array}$ & 74 & 62 & -12 & 77 & 66 & -11 \\
\hline $\begin{array}{l}\text { P501SRCO } \times \\
\text { P502SRCO }\end{array}$ & 88 & 75 & -13 & 93 & 78 & -15 \\
\hline BGBYPOP & 91 & 77 & -14 & 95 & 79 & -16 \\
\hline \multicolumn{7}{|l|}{ QPM Full season } \\
\hline S99TLYQ-B & 75 & 75 & 0 & 80 & 80 & 0 \\
\hline S99TLYQ-AB & 59 & 68.5 & +9.5 & 64 & 73 & +9 \\
\hline SO1SIWQ-3 & 76 & 70 & -6 & 79 & 75 & -4 \\
\hline \multicolumn{7}{|l|}{ OPV Early } \\
\hline Pool-17 & 59 & 53 & -6 & 60 & 58 & -2 \\
\hline Arun-1EV & 54 & 53 & -1 & 56 & 57 & -1 \\
\hline Arun-4 & 58 & 62 & +4 & 62 & 65 & +3 \\
\hline $\mathrm{CV} \%$ & 1.7 & 2.4 & & 1.4 & 2.9 & \\
\hline LSD (0.05) & 2.82 & 3.68 & & 2.3 & 4.61 & \\
\hline F-test & $* *$ & $* *$ & & $* *$ & $* *$ & \\
\hline
\end{tabular}

** Significant at 0.01 level of significance

Table 2. Comparative study of maize genotypes derived from original and selected population for plant height and ear height at Rampur, Chitwan, 2011-12 winter season

\begin{tabular}{|c|c|c|c|c|c|c|}
\hline \multirow[t]{2}{*}{ Genotypes } & \multicolumn{3}{|c|}{ Plant height (cm) } & \multicolumn{3}{|c|}{ Ear height (cm) } \\
\hline & $\begin{array}{c}\text { Original } \\
\text { population }\end{array}$ & $\begin{array}{c}\text { Selected } \\
\text { population }\end{array}$ & Difference & $\begin{array}{c}\text { Original } \\
\text { population }\end{array}$ & $\begin{array}{c}\text { Selected } \\
\text { population }\end{array}$ & Difference \\
\hline \multicolumn{7}{|l|}{ OPV Full season } \\
\hline $\begin{array}{l}\text { Across } 9942 \times \\
\text { Across } 9944\end{array}$ & 240 & 214 & -26 & 112 & 100 & -12 \\
\hline $\begin{array}{l}\text { P501SRCO } \times \\
\text { P502SRCO }\end{array}$ & 223 & 194 & -29 & 117 & 100 & -17 \\
\hline BGBYPOP & 220 & 80 & -40 & 114 & 108 & -6 \\
\hline \multicolumn{7}{|l|}{ QPM Full season } \\
\hline S99TLYQ-B & 212 & 202 & -10 & 112 & 102 & 10 \\
\hline S99TLYQ-AB & 216 & 163 & -53 & 99 & 81 & -18 \\
\hline SO1SIWQ-3 & 211 & 158 & -53 & 110 & 95 & -15 \\
\hline \multicolumn{7}{|l|}{ OPV Early } \\
\hline Pool-17 & 210 & 205 & -5 & 82 & 81 & -1 \\
\hline Arun-1EV & 221 & 211 & -10 & 108 & 106 & -2 \\
\hline Arun-4 & 185 & 180 & -5 & 78 & 73 & -5 \\
\hline $\mathrm{CV} \%$ & 2.5 & 4.1 & & 4.9 & 25.7 & \\
\hline $\operatorname{LSD}(0.05)$ & 11.58 & 18.46 & & 11.41 & 51.33 & \\
\hline F-test & $* *$ & $* *$ & & $* *$ & $\mathrm{~ns}$ & \\
\hline
\end{tabular}

ns: Non significance, $* *$ Significant at 0.01 level of significance 
Shrestha, Kunwar and Bhandari / Our Nature (2018), 16 (1): 35-42

Table 3. Comparative study of maize genotypes derived from original and selected population for plant aspect and ear aspect at Rampur, Chitwan, 2011-12 winter season

\begin{tabular}{|c|c|c|c|c|c|c|}
\hline \multirow[t]{2}{*}{ Genotypes } & \multicolumn{3}{|c|}{ Plant aspect (1-5) } & \multicolumn{3}{|c|}{ Ear aspect (1-5) } \\
\hline & $\begin{array}{c}\text { Original } \\
\text { population }\end{array}$ & $\begin{array}{c}\text { Selected } \\
\text { population }\end{array}$ & $\begin{array}{c}\text { Differenc } \\
\mathrm{e}\end{array}$ & $\begin{array}{c}\text { Original } \\
\text { population }\end{array}$ & $\begin{array}{c}\text { Selected } \\
\text { population }\end{array}$ & $\begin{array}{c}\text { Differenc } \\
\text { e }\end{array}$ \\
\hline \multicolumn{7}{|l|}{ OPV Full season } \\
\hline $\begin{array}{l}\text { Across } 9942 \times \\
\text { Across } 9944\end{array}$ & 2.6 & 1.9 & -0.7 & 2 & 2 & 0 \\
\hline $\begin{array}{l}\text { P501SRCO } \times \\
\text { P502SRCO }\end{array}$ & 2.9 & 2.1 & -0.8 & 2.7 & 2.2 & -0.5 \\
\hline BGBYPOP & 2.3 & 1.3 & -1.0 & 2 & 2.1 & +0.1 \\
\hline \multicolumn{7}{|l|}{ QPM Full season } \\
\hline S99TLYQ-B & 2.6 & 1.5 & -1.1 & 2.8 & 1.4 & -1.4 \\
\hline S99TLYQ-AB & 2.8 & 1 & -1.8 & 1.9 & 1 & -0.9 \\
\hline SO1SIWQ-3 & 2.5 & 1.7 & -0.8 & 2.3 & 1.8 & -0.5 \\
\hline \multicolumn{7}{|l|}{$\underline{\text { OPV early }}$} \\
\hline Pool-17 & 3 & 2.1 & -0.9 & 3 & 1.6 & -1.4 \\
\hline Arun-1EV & 3 & 1.2 & -1.8 & 2.5 & 2 & -0.5 \\
\hline Arun-4 & 2.5 & 1.1 & -1.4 & 3 & 1.3 & -1.7 \\
\hline $\mathrm{CV} \%$ & 10.7 & 21 & & 14.5 & 8 & \\
\hline $\operatorname{LSD}(0.05)$ & 0.66 & 0.778 & & 0.82 & 0.316 & \\
\hline F-test & $\mathrm{ns}$ & ns & & ns & $* *$ & \\
\hline
\end{tabular}

ns: Non significance, $* *$ Significant at 0.01 level of significance

lower than original population of OPV early. In this study the difference in ear aspect reduction was higher in QPM than the OPV full season and OPV early because of more selection pressure was given to QPM varieties than other varieties (Table 3).

\section{Disease score}

The disease (BLSB and ear rot) score in maize genotypes was significant. The disease score was reduced in selected population as compared to original population (Table 4).

There was not improvement in disease severity in case of Maydis between the original and selected population of tested genotypes. However, disease severity has been reduced in case of BLSB on BGBYPOP, S99TLYQ-AB and Pool 17. Similarly, disease severity in case of ear rot has been significantly reduced on Across9942 $\times$ Across9944, S99TLYQ-B, S99TLYQ-AB, SO1SIWQ-3 and Pool-17. The maize disease severity was increased in P501SRCO $\times$ P502SRCO in selected population as compared to its original population which leads to grain yield reduction in selected population of this genotype.

\section{Grain yield}

The grain yield difference was observed by 909 $\mathrm{kg} / \mathrm{ha}$ reduction in P501SRCO $\times$ P502SRCO but the grain difference increased by $639 \mathrm{~kg} / \mathrm{ha}$ in Across $9942 \times$ Across 9944 and $1051 \mathrm{~kg} / \mathrm{ha}$ in BGBYPOP in selected population of OPV full season than their original population. The grain yield difference was observed 295 to $1194 \mathrm{~kg} / \mathrm{ha}$ higher than original population of QPM varieties whereas, 75 to $392 \mathrm{~kg} / \mathrm{ha}$ higher than original population in case of OPV early. In this study the difference in grain yield increment was higher in QPM than the OPV full season and OPV early because of more selection pressure was given to QPM varieties than other varieties.

The grain yield was significant for genotypes (Table 5). The genotypes of selected population produced higher grain yield than that of the original population except the genotype namely P501SRCO $\times$ P502SRCO. This showed that genetic progress was made through five cycles of selection resulting in significant improvement in yield. This significant increase in grain yield of the selected population may be attributed toward improvement in other physiological and yield related traits. 
Table 4. Comparative study of maize genotypes derived from original and selected population for disease severity at Rampur, Chitwan, 2011-12 winter season

\begin{tabular}{|c|c|c|c|c|c|c|}
\hline \multirow[t]{2}{*}{ Genotypes } & \multicolumn{2}{|c|}{ Maydis (1-5) } & \multicolumn{2}{|c|}{ BLSB (1-5) } & \multicolumn{2}{|c|}{ Ear rot (1-5) } \\
\hline & $\begin{array}{c}\text { Original } \\
\text { population }\end{array}$ & $\begin{array}{c}\text { Selected } \\
\text { population }\end{array}$ & $\begin{array}{c}\text { Original } \\
\text { population }\end{array}$ & $\begin{array}{c}\text { Selected } \\
\text { population }\end{array}$ & $\begin{array}{c}\text { Original } \\
\text { population }\end{array}$ & $\begin{array}{c}\text { Selected } \\
\text { population }\end{array}$ \\
\hline \multicolumn{7}{|l|}{$\underline{\text { OPV Full season }}$} \\
\hline $\begin{array}{l}\text { Across } 9942 \times \\
\text { Across } 9944\end{array}$ & 2 & 2 & 2.3 & 2 & 3 & 1 \\
\hline $\begin{array}{l}\text { P501SRCO } \times \\
\text { P502SRCO }\end{array}$ & 2 & 2.8 & 2 & 2.4 & 1 & 1.1 \\
\hline BGBYPOP & 1.5 & 1.5 & 2.6 & 2 & 1.4 & 1 \\
\hline \multicolumn{7}{|l|}{ QPM Full season } \\
\hline S99TLYQ-B & 3 & 3 & 2.5 & 2.5 & 1.6 & 1.2 \\
\hline $\begin{array}{l}\text { S99TLYQ-AB } \\
\text { SO1SIWQ-3 }\end{array}$ & $\begin{array}{l}2 \\
2\end{array}$ & $\begin{array}{l}2 \\
2\end{array}$ & $\begin{array}{l}2.9 \\
2.4\end{array}$ & $\begin{array}{l}2 \\
2\end{array}$ & $\begin{array}{l}1.7 \\
2.6\end{array}$ & $\begin{array}{l}1 \\
2\end{array}$ \\
\hline \multicolumn{7}{|l|}{ OPV Early } \\
\hline Pool-17 & 2.6 & 2.8 & 3.6 & 3 & 3.7 & 3 \\
\hline Arun-1EV & 2.3 & 2.5 & 4.3 & 4 & 3.3 & 3.3 \\
\hline Arun-4 & 2.3 & 2.3 & 3.3 & 3 & 2.3 & 2.3 \\
\hline $\mathrm{CV} \%$ & 20.1 & 9.2 & 6.7 & 8.8 & 12.2 & 15.2 \\
\hline LSD (0.05) & 1.05 & 0.492 & 0.45 & 0.508 & 0.652 & 0.619 \\
\hline F-test & ns & $* *$ & $* *$ & $* *$ & $* *$ & $* *$ \\
\hline
\end{tabular}

ns: Non significance, $* *$ Significant at 0.01 level of significance

Table 5. Comparative study of maize genotypes derived from original and selected population for grain yield at Rampur, Chitwan, 2011-12 winter season

\begin{tabular}{|c|c|c|c|}
\hline \multirow[t]{2}{*}{ Genotypes } & \multicolumn{3}{|c|}{ Grain yield (kg/ha) } \\
\hline & Original population & Selected population & Difference \\
\hline \multicolumn{4}{|l|}{ OPV Full season } \\
\hline Across $9942 \times$ Across 9944 & 4305 & 4944 & +639 \\
\hline P501SRCO $\times$ P502SRCO & 5210 & 4301 & -909 \\
\hline BGBYPOP & 4504 & 5555 & +1051 \\
\hline \multicolumn{4}{|l|}{ QPM Full season } \\
\hline S99TLYQ-B & 5456 & 6014 & +558 \\
\hline S99TLYQ-AB & 5013 & 5308 & +295 \\
\hline SO1SIWQ-3 & 4204 & 5398 & +1194 \\
\hline \multicolumn{4}{|l|}{ OPV Early } \\
\hline Pool-17 & 3710 & 3800 & +90 \\
\hline Arun-1EV & 4405 & 4480 & +75 \\
\hline Arun-4 & 4209 & 4601 & +392 \\
\hline $\mathrm{CV} \%$ & 5.7 & 29.8 & \\
\hline $\operatorname{LSD}(0.05)$ & 604 & 1116.5 & \\
\hline F-test & $*$ & $*$ & \\
\hline
\end{tabular}

* Significant at 0.05 level of significance 


\section{Discussion}

The effects of mass selection on grain yield and other agronomic traits were studied. The comparative study between original maize population and the population derived after five cycles of mass selection was carried out. The grain yield was found higher in maize population derived from five cycle's mass selection. The present study was similar to findings of JasaVega (1985) who observed the increase in grain yield in maize by mass selection. The results are in accordance with the results reported by Gardner (1961, 1969), Johnson (1963), Lonnquist (1967), Arboleda-Rivera and Compton (1974), Taran et al. (2004) and Rahman et al. (2007) who noted substantial grain yield gains in maize populations following mass selection. Mass selection significantly increased grain yield 12 to $15 \%$ on the average in maize (Mareck and Gardner, 1979). The reduction in plant height in mass selected population was highly significant for genotypes. This finding was similar to Khan et al. (1983) who found that the maize population developed by mass selection was lower in plant height than their original population. Miles et al. (1980) noticed that the mass selection was the most efficient method of improving disease resistance in maize populations. This results presented here concur with the results previously described for the Portuguese Pigarro maize population (Vaz Patto et al., 2008) where stratified mass selection demonstrated to be an effective way to conserve diversity on-farm, and at the same time allowed relevant phenotypic improvements to be achieved.

\section{Conclusion}

The phenotypic superiority of maize genotypes in population derived from five cycles of mass selection over the original population was obvious. The maize genotypes derived after five cycles of selection manifested the higher grain yield, lesser plant height and ear height, better plant and ear aspect, lesser disease and insect infestation as well as earlier in silking and tasseling days as compared with that parameters of the original population. Thus, the five cycles of mass selection were found effective for improvement of agronomic traits in maize populations.

\section{Acknowledgements}

The support of Dr. Dil Bahadur Gurung, the ExCoordinator of National Maize Research Program, Rampur, Chitwan, Nepal is hereby gratefully acknowledged in terms of his research guidance and providing research materials. Nepal Agricultural Research Council is acknowledged for funding to carry out this experiment. Moreover, the authors were thankful to National Maize Research Program, Rampur, Chitwan for providing research field.

\section{References}

Arboleda-Rivera, F. and W.A. Compton 1974. Differential response of maize (Zea mays L.) to mass selection in diverse selection environments. Theor. Appl. Genet 44: 77-81.

Bell, R.D., L.L. Darrah and M.S. Zuber 1983. Progress from mass selection for field emergence and seed weight in a sh2 population of maize. Crop Sci 23: 461-464.

Biasutti, C.A., F. Casanoves and D.A. Peiretti 2000. Response to different adaptive mass selection criteria in a maize exotic population. Maydica 45: 89-94.

Carangal, V.R., S.M. Ali, A.F. Koble, E.H. Rinke and J.C. Sentz 1971. Comparison of S1 with testcross evaluation for recurrent selection in maize. Crop Science 11: 658-661.

Cortez-Mendoza, H. and A.R. Hallauer 1979. Divergent mass selection for ear length in maize. Crop Sci 19: 175-178.

Darrah, L.L., S.A. Eberhart and L.H. Penny 1978. Six years of maize selection in Kitale synthetic II. Euphytica 27: 191-204.

Eberhart, S.A., M.N. Harrison and F. Ogada 1967. A comprehensive breeding system. Zuechter 17: 451- 456.

Gardner, C.O. 1961. An evaluation of effects of mass selection and seed irradiation with thermal neutrons on yield of corn. Crop Sci. 1: 241-245.

Gardner, C.O. 1969. The role of mass selection and mutagenic treatment in modern corn breeding. In Proceedings of the 24th Corn Research Conference, American Seed Trade Association. pp. $15-21$.

Gardner, C.O. 1977. Quantitative genetic studies and population improvement in maize and sorghum. In Proc. Int. Conf. Quant. Genet (Pollak, E, O. Kempthorne and T.B. Bailey Eds.). Iowa State Univ. Press, Ames, IA. pp 475-489.

Gomez, K.A. and A.A. Gomez.1984. Statistical procedures for agricultural research. 2nd ed., International Rice Research Institute, College, Laguna, 680p.

Hallauer, A.R., M.J. Carena and J. D. Miranda Filho 2010. Quantitative genetics in maize breeding. Vol. 6. Springer, New York.

Jasa-Vega, P.J. 1985. Divergent mass selection for line two synthetic reported in a maize (Zea mays L.) population. Disser. Abst. International 45(11): 3422. 
Johnson, E.C. 1963. Mass selection of yield in a tropical corn variety. Amer. Soc. Agron. Abstr. $82 \mathrm{p}$.

Khan, M.S. 1983. Improvement of a population of maize (Zea mays L.) for Pakistan. Disser. Abst. International 43(7):2072

Lonnquist, J.H. 1967. Mass selection for prolificacy in corn. Der Zuchter 37: 185-188.

Mareck, J.H. and C.O. Gardner 1979. Responses to mass selection in Maize and stability of resulting populations1. Crop Sci 19:779-783. DOI:10.2135/cropsci1979.0011183X0019000600 $08 \mathrm{x}$

Miles, J.W., J.W. Dudley, D.G. White and R.J. Lambert 1980. Improving corn population for grain yield and resistance to leaf blight and stalk Rot. Crop Sci 20: 247-251.

Odhiambo, M.O. and W.A. Compton 1987. Twenty cycles of divergent mass selection for seed size in corn. Crop Sci 27: 1113-1116.

Rahman, H., I.H. Khalil, N. Islam, Durrishahwar and A. Rafi 2007. Comparison of original and selected maize populations for grain yield traits. Sarhad J. Agric 23: 641-644.

Salazar, A.M. and A.R. Hallauer 1986. Divergent mass selection for ear length in maize. Rev. Bras.
Genet 9: 281-294.

Shrestha, J., D.N. Yadav, L.P. Amgain and J.P. Sharma. 2018. Effects of nitrogen and plant density on maize (Zea mays L.) phenology and grain yield. Current Agriculture Research Journal, 6(2): 175-182.

Subandi, W. 1990. Ten cycles of selection for prolificacy in a composite variety of maize. Indonesian J. Crop Sci 5: 1-11.

Taran, S.A., S. Nasibullah, M.A. Mian and H. Shah 2004. Genetic improvement through mass selection in maize (Zea mays L.). J. App. Em. Sc 1: 152-157.

Vargas, S., J.E. Molina, J.D. Galan and S.T. Cervantia 1982. Mass selection and genetic parameters in the maize variety Zac. Agrociencia 48: 93-105.

Vaz Patto, M.C., P.M. Moreira, N. Almeida, Z. Satovic and S. Pego 2008. Genetic diversity evolution through participatory maize breeding in Portugal. Euphytica 161: 283-291.

Zorilla, H.L. and P.L. Crane 1982. Evaluation of three cycles of fullsib family selection for yield in the Col us 02 variety of maize. Crop Sci 22: 10-12. 